Literature and Nation in the

Sixteenth

Century 



\section{Literature and}

INVENTING

Nation in the

RENAISSANCE

\section{Sixteenth}

FRANCE

Century

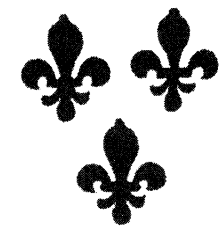

TIMOTHY HAMPTON

Cornell University Press

ITHACA \& LONDON 
Copyright (C) 200 r by Cornell University

All rights reserved. Except for brief quotations in a review, this book, or parts thereof, must not be reproduced in any form without permission in writing from the publisher. For information, address Cornell University Press, Sage House, 512 East State Street, Ithaca, New York 14850.

First published $200 \mathrm{r}$ by Cornell University Press

Printed in the United States of America

Library of Congress Cataloging-in-

Publication Data

Hampton, Timothy.

Literature and nation in the sixteenth century : inventing Renaissance France / by Timothy Hampton.

p. cm.

Includes bibliographical references.

ISBN 0-8014-3774-I

I. French literature-16th century-History and criticism. 2. Nationalism in literature. I. Title.

$\mathrm{PQ}_{239 . \mathrm{H}_{2} 62000}$

$840.9^{\prime} 358-\mathrm{dc} 21$

00-010240

Cornell University Press strives to use environmentally responsible suppliers and materials to the fullest extent possible in the publication of its books. Such materials include vegetable-based, lowVOC inks and acid-free papers that are recycled, totally chlorine-free, or partly composed of nonwood fibers.

For further information, visit our website at www.cornellpress.cornell.edu.

Cloth printing

I0 $98 \quad 7$

654

32

I 
for my mother,

who encouraged me to go to school 
